\title{
EFFECTS OF PYRIMETHANIL ON POLLEN MEIOSIS OF TOMATO PLANT (LYCOPERSICON LYCOPERSICUM MILL.) TeOMAn KeSERC OĞLU ${ }^{*}$ AND LKAY ÖZTürk ÇALI ${ }^{1}$ 9 Eylül Üniversitesi, Buca Ĕ̆itim Fakültesi, lköğretim Bölümü Fen Bilgisi Anabilim Dall, 35160, Buca-zmir/ Türkiye
}

Key words: Lycopersicon lycopersicum, Pyrimethanil, Meiosis, Pollen

\begin{abstract}
Effects of Mythos SC 300 (300 g/l pyrimethanil), a fungicide on tomato plants were studied by observation of pollen meiosis. The fungicide was applied at double the recommended dosage $(250 \mathrm{ml} / 1001$ tap water). The anthers of flower bud fixed in Carnoy's fluid were stained with $2 \%$ aceto-orcein. The fungicide caused various anomalies in pollen meiosis, decrease in pollen yield and consequently influenced future seed formation.
\end{abstract}

Application of excessive dosages of pesticides brings on utmost residue problems which affect human and animal health. Pesticides used ignorantly pollute nature and could result a decrease in sensitivity of organisms against these chemicals (Durmuşoğlu 2002).

Pesticides used in excessive dosages may give rise to abnormal chromosome beheviour such as formation of micronuclei, chromosome bridges and polyploidy in different plant species (Tosun et al. 2001, Fairbanks et al. 2002).

This study aims to investigate effects of overdose application of Mythos SC 300, a fungicide intensively used in greenhouse conditions in Turkey against grey mould (Botrytis cinerea), on pollen meiosis of tomato.

This work was carried out in Plant Protection Greenhouse, Faculty of Agriculture, Ege University. Healthy tomato seedlings were obtained from M-19 $\mathrm{F}_{1}$ type domestic seeds. Mythos SC 300 [300 g/l pyrimethanil (N-(4,6-dimethylpyrimidin-2-yl) aniline)], a fungicide used in the trial was sprayed on tomato seedlings grown in pots. The fungicide was applied at $250 \mathrm{ml} / 100 \mathrm{l}$ tap water, at double the recommended dosage, five times at ten-day intervals. Specimens randomly collected from different plants were fixed in Carnoy's fluid. Anthers were stained with $2 \%$ acetoorcein before being squashed (Östergren and Heneen, 1962).

Cell shapes, cell division patterns, cell sizes and bivalent arrangements of a total of 100 pollen mother cells (PMCs) for each group were observed and photographed using a Jena microscope. Statistical analysis of the values obtained from all the measurements in the study was made on a SPSS 11.0 for Windows Statistical Program, and the variance analyses were made using the Chisquare test, a nonparametric test widely utilized in such procedures.

Data of the cell shapes of pollens in the control and the treated plants are given in Table 1. The number of round pollens in the treatment was lower than the control, whereas the number of oval and abnormally shaped pollens was higher. These fluctuations in the values were also found to be significant as compared to the control group. On the other hand, presence of rectangularshaped pollens was not seen in the control but observed after treatment (Figs. 1, 2).

Fungicide applications caused degeneration of developing pollen and also retarded growth of catkins with detrimental effects on stigma and pollen morphology in the $125 \mathrm{ml} / 100$ dosage of Mythos SC 300 fungicide (Tort et al. 2005, Prakash et al. 1988, He and Wetzstein 1994, Yi et al. 2002). In this study, it was determined that the fungicide application changed pollen shape compared to that of control and increased in the number of abnormal pollen shape.

*Corresponding author. E-mail: teoman.koglu@deu.edu.tr. ${ }^{1}$ Ege University, Science Faculty, Department of Botany, 35100, Bornova- zmir/Turkey. 
Effect of Mythos SC 300 fungicide on bivalents in tomato PMCs are shown in Table 2. The number of distinct bivalents in the treated plants was lower as compared to the control, whereas the number of univalent ones was higher in the treated plants.

Table 1. Comparison of pollen shapes in control and fungicide applied groups.

\begin{tabular}{lcccc}
\hline $\begin{array}{l}\text { Application } \\
\text { groups }\end{array}$ & Round & Oval & Rectangular & Abnormal cells \\
\cline { 2 - 5 } Control & 80 & 19 & 0 & 1 \\
Mythos $250 \mathrm{ml} / 1001$ & 10 & 49 & 1 & 40 \\
\hline
\end{tabular}

These fluctuations in the values were found to be significant as compared to the control. On the other hand, the number of chromosome abnormalities such as linear,binding and polar distortion increased in the treated plants as compared to the control. Increase in binding chromosome abnormalities was found to be significant (Table 2, Fig. 2). The Tables show that the differences among control and $250 \mathrm{ml} / 1001$ Mythos group are statistically significant $(\mathrm{p}<0.05)$.
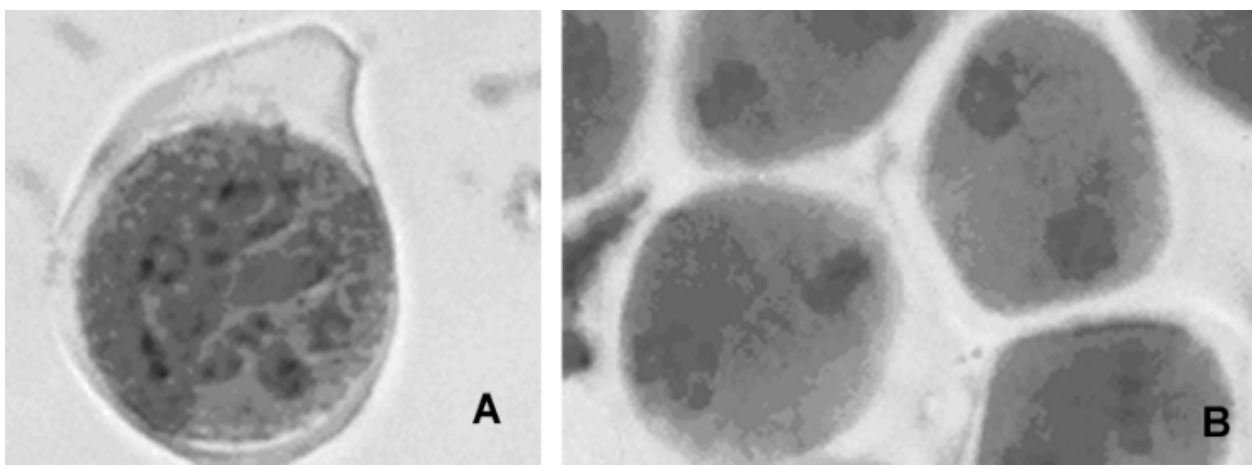

Fig. 1. Different meiotic phases of the control group. A. Metaphase I. B. Telophase I.

Chromosome abnormalities due to application of different pesticides was also reported earlier. Application of phosphomidon led to linear abnormalities in red pepper (Devadas et al. 1986). Methamidophos applications were responsible for chromosome abnormalities in the form of stickiness in Vicia faba (Amer and Farah 1987). Some pesticides caused chromosome abnormalities such as polar distortion. Çelik and Sümer (1996) found polar distortaion by the

Table 2. Arrangement of bivalents in pollens of control and fungicide applied groups.

\begin{tabular}{lccccc}
\hline $\begin{array}{l}\text { Application } \\
\text { groups }\end{array}$ & Distinct & Indistinct & Linear & Binding & Polar distortion \\
\cline { 2 - 6 } Control & 84 & 16 & 1 & 1 & 0 \\
Mythos $250 \mathrm{ml} / 1001$ & 45 & 55 & 4 & 40 & 35 \\
\hline
\end{tabular}

application of some other pesticides. Incensement in chromosome abnormalities was inversely proportional to the pollen yield. Besides it was stated that there was a relation between pollen unproductiveness and chromosome damage in pollens (Reddy and Rao 1981).

Results of cell division patterns and cell sizes related to the control and the fungicide treatment plants are given in Table 3. The number of properly divided and normal-sized cells 
decreased in the treated plants as compared to the control, whereas the numbers of improperly divided as well as large and small sized cells increased (Fig. 2).

Table 3. Cell division patterns and pollens sizes in control and fungicide applied groups.

\begin{tabular}{lccccc}
\hline $\begin{array}{l}\text { Application } \\
\text { groups }\end{array}$ & \multicolumn{2}{c}{ Cell division patterns } & Cell size & Small \\
\cline { 2 - 6 } Control & Proper & Inproper & Normal & Large & 0 \\
Mythos $250 \mathrm{ml} / 1001$ & 99 & 1 & 99 & 1 & 6 \\
\hline
\end{tabular}

The decrease in normal sized cells in the Mythos SC 300 group, the increase in improperly divided cells and large cells were found to be significant. Improperly divided, large and small cells found in this study were also observed in some pesticide applications as well (Amer and Farah 1983, Ajay and Sarbhoy 1987).
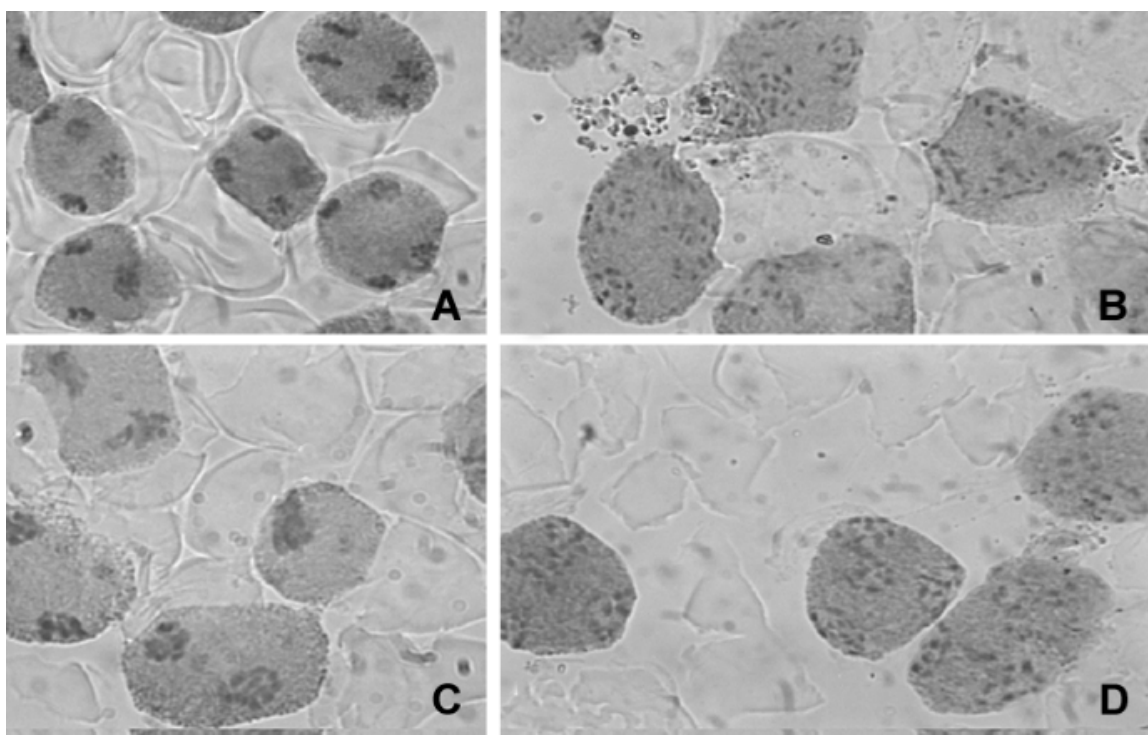

Fig. 2. Abnormal meiotic division after Mythos $250 \mathrm{mg} / 1001$ treatment. A. Rectangular cell shape. B. Abnormal shape. C. Binding, polar sliding and small cell. D. Large cell.

From the foregoing discussion it appeared that overdose application $(250 \mathrm{ml} / 100 \mathrm{l})$ of Mythos SC 300 fungicide (that intensively used in greenhouse conditions in Turkey), caused different cytological anomalies on pollen meiosis which affected pollen yield negatively. Therefore, the recommended dosage for application of these pesticides must be followed.

\section{Acknowledgements}

The authors thank Professor Dr Ulvi Zeybek for allowing to carry out the work in the Laboratory of the Faculty of Pharmacology, Ege University.

\section{References}

Ajay, K.J. and R.K. Sarbhoy. 1987. Cytogenetical studies on the effect of some chlorinated pesticides. II.

Effect on meiotic chromosomes of Lens and Pisum. Cytologia 52: 55-61. 
Amer, S.M. and O.R. Farah. 1983. Cytological effects of pesticides. XIII. Meiotic effects of the insecticide "Dursban". Cytologia 48: 557-563.

Amer, S.M. and O.R. Farah. 1987. Cytological effects of pesticides. VIII. Meiotic effects of the insecticide Methamidophos. Cytologia 52: 303-307.

Çelik, T.A. and Ş. Sümer. 1996. Basudin (20 EM) in arpa mitotik kromozomları üzerine etkileri. Tr. J. Biol. 20: $21-28$.

Devadas, N., V.R. Manchikatla and K. Subash. 1986. Comparative mutagenicity of four organophosphorous insecticides in meiotic system of red pepper. Cytologia 51: 645-653.

Durmuşoğlu, E. 2002. zmir'de pazara sunulan domates ve hıyarlarda bazı organik fosforlu insektisit kalıntılarının saptanması üzerinde araştırmalar. Türk. Entomol. Derg. 26(2): 93-104.

Fairbanks, M.M., G.E.St J. Hardy and J.A. McComb. 2002. Mitosis and meiosis in plants are affected by fungicide phosphite. Australasian Plant Path. 31(3): 281-289.

He, Y. and H.Y. Wetzstein. 1994. Pollen degeneration and retarded leaf devolopment from fungicidal sprays applied during microspore development and shoot expansion. J. Hortic. Sci. 69: 975-983.

Östergren, G. and W.K. Heneen. 1962. A squash technique for chromosome morphological studies. Hereditas 48: 332-342.

Prakash, N.S., N. Lakshmi and I. Harini. 1988. Cytological effects of agricultural chemicals II. Effects of fungicides "Bavistin" and 'Deltan' on chilli. Cytologia 53: 709-715.

Reddy, S.S. and G.M. Rao. 1981. Cytogenetic effects of agricultural chemicals I. Effects of insecticides "BHC and Nuvacron"on chromosomes in Chilli. Cytologia 46: 699-707.

Tort, N., . Öztürk and A. Güvensen. 2005. Effects of some fungicides on pollen morphology and anatomy of tomato (Lycopersicon esculentum Mill.). Pak. J. Bot. 37(1): 23-30.

Tosun, N., Ü. Karabay and F. Sayım. 2001. Pesticide usage and their potential adverse impacts on living organism. Anadolu. J. AARI. 1(1): 113-125.

Yi, W., S.E. Law and H.Y. Wetzstein. 2002. Fungicide sprays can injure the stigmatic surface during receptivity in almond flowers. Ann. Bot. 91: 1-7.

(Manuscript received on 10 December, 2006; revised on 12 March, 2007) 